\title{
DNA and RNA Can Be Equally Efficient Catalysts for Carbon-Carbon Bond Formation
}

\author{
Madhavaiah Chandra and Scott K. Silverman* \\ Department of Chemistry, University of Illinois at Urbana-Champaign, 600 South Mathews Avenue, Urbana, IL 61801
}

\section{Table of Contents}

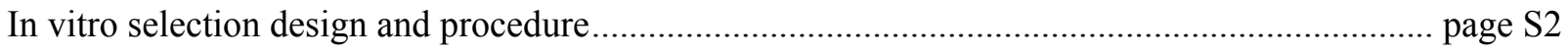

Cloning and activity assays of individual Diels-Alder deoxyribozymes ................................... page S4

Additional activity assays of individual Diels-Alder deoxyribozymes ....................................... page S5

In cis kinetic assays of the DAB22 deoxyribozyme.................................................................. page S5

In trans kinetic assays of the DAB22 deoxyribozyme ........................................................... page S6

ESI-MS to verify the in trans DAB22 reaction product identity ............................................. page S7

Determination of $K_{\text {d,app }}$ for $\mathrm{Ca}^{2+}$ for DAB22 in trans ......................................................... page $\mathrm{S} 7$

Dependence of the DAB22 deoxyribozyme on metal ion identity .......................................... page S8

Testing the secondary structure of the DAB22 deoxyribozyme................................................. page S8

Rate enhancements for the DAB22 deoxyribozyme and 39M49 ribozyme ................................ page S10

Michaelis-Menten $K_{\mathrm{m}}$ values for the DAB22 deoxyribozyme and 39M49 ribozyme................... page S11

References for Supporting Information........................................................................... page S14 
$\underline{\text { In vitro selection design and procedure }}$

Nucleic acid substrates and primers. The DNA sequences of the DAR and DAB pools were (5'-AnthrHEG)GGAGCTCGCTTGTCG-N ${ }_{40 / 36}$-AGCTGATCCTGATGG-3', where Anthr-HEG denotes anthracene attached via a hexaethylene glycol spacer. ${ }^{1,2}$ For DAR, $\mathrm{N}_{40}$ was 40 fully random nucleotides. For DAB, $\mathrm{N}_{36}$ was derived from nt 20-49 of the 39M49 ribozyme, ${ }^{3}$ with each nucleotide $30 \%$ randomized (i.e., $70 \%$ as the nucleotide from the 39M49 sequence, and 10\% for each of the other three nucleotides). The initial pool for the DAR selection was prepared by primer extension using the reverse complement of the pool as template (see full procedure in next paragraph). At the 5'-end of the reverse complement was placed $5^{\prime}-\mathrm{C}(\mathrm{AAC})_{4} \mathrm{X}$, where $\mathrm{X}$ denotes Glen Spacer 18 (PEG) to permit PAGE separation of the primer extension product strand from the reverse complement template strand. The forward primer for the extension reaction, primer 2 (5'-Anthr-HEG-GGAGCTCGCTTGTCG-3'), was prepared with with Anthr-HEG incorporated at the $5^{\prime}$-terminus using the Anthr-HEG phosphoramidite prepared as described below. ${ }^{1,2}$ The initial pool for the DAB selection was prepared by solid-phase synthesis at IDT, using phosphoramidite mixtures that were corrected for unequal coupling efficiencies, ${ }^{4}$ with Anthr-HEG incorporated at the 5'terminus using the Anthr-HEG phosphoramidite. Primer 1t, 5'-(AAC) ${ }_{4}$ XCCATCAGGATCAGCT-3' where X denotes Glen Spacer 18, was synthesized at IDT. Primer 2 was synthesized at the UIUC Biotechnology Center; the Anthr-HEG phosphoramidite was coupled for $2 \times 10$ min with no intermediate capping step to improve the incorporation efficiency. All oligonucleotides were purified by denaturing PAGE with running buffer $1 \times$ TBE $(89 \mathrm{mM}$ each Tris and boric acid and $2 \mathrm{mM}$ EDTA, $\mathrm{pH} 8.3)$ as described previously. ${ }^{5,6}$

Primer extension to generate the DAR initial pool was performed as follows. A $100-\mu \mathrm{L}$ sample containing $100 \mathrm{pmol}$ of reverse complementary pool, 300 pmol of Anthr-HEG primer 2, 1× of NEB ThermoPol buffer $\left(20 \mathrm{mM}\right.$ Tris- $\mathrm{HCl}, \mathrm{pH} 8.8,10 \mathrm{mM}\left(\mathrm{NH}_{4}\right)_{2} \mathrm{SO}_{4}, 10 \mathrm{mM} \mathrm{KCl}, 2 \mathrm{mM} \mathrm{MgSO}$, $0.1 \%$ Triton $\mathrm{X}-100), 300 \mu \mathrm{M}$ of each $\mathrm{dNTP}$, and 5 units of Taq polymerase was subjected to 25 PCR cycles (conditions: $94{ }^{\circ} \mathrm{C}$ for $2 \mathrm{~min}$, then cycles of $94{ }^{\circ} \mathrm{C}$ for $30 \mathrm{~s}, 47{ }^{\circ} \mathrm{C}$ for $30 \mathrm{~s}$, and $72{ }^{\circ} \mathrm{C}$ for $30 \mathrm{~s}$, with the final cycle continued for $5 \mathrm{~min}$ at $72{ }^{\circ} \mathrm{C}$ ). The sample was diluted to $180 \mu \mathrm{L}$ with $80 \mu \mathrm{L}$ of water, precipitated with $20 \mu \mathrm{L}$ of $3 \mathrm{M} \mathrm{NaCl}$ and $600 \mu \mathrm{L}$ of ethanol, and purified by $8 \%$ denaturing PAGE. As assessed by UV absorbance $\left(\mathrm{A}_{260}\right), 75-100$ pmol of primer extension product was obtained.

The selection size standard for PAGE was designed and prepared as follows. The selection product after conjugation with the 16-nt 3'-thiol-modified oligo was $86 \mathrm{nt}$, with additional mass due to the AnthrHEG-DTME Diels-Alder adduct (MW 27463, computed for random $\mathrm{N}_{40}$ region). To prepare a standard of similar molecular weight, a 70-nt RNA transcript was ligated to a 5'-phosphorylated 16-nt 3'-thiolmodified DNA using a 31-nt DNA splint and T4 DNA ligase. The resulting 86-nt ligation product (MW 27832) was purified by $8 \%$ denaturing PAGE, dephosphorylated with CIP, and $5^{\prime}-{ }^{32} \mathrm{P}$-radiolabeled with $\gamma-{ }^{32} \mathrm{P}-\mathrm{ATP}$ and T4 PNK.

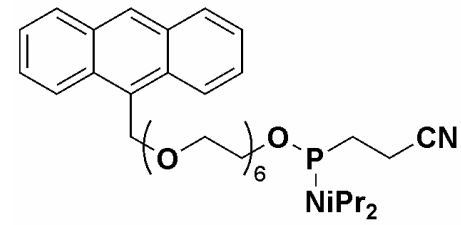

The Anthr-HEG phosphoramidite was prepared as described, with modifications to improve the reported yield of $58 \% .^{2}$ (9-Anthracenylmethyl)hexaethylene glycol $(0.16 \mathrm{~g}, 0.33 \mathrm{mmol})$ was coevaporated with dry $\mathrm{CH}_{2} \mathrm{Cl}_{2}$ and dried under vacuum for $3 \mathrm{~h}$. The yellow oil was dissolved in $1 \mathrm{~mL}$ of dry $\mathrm{CH}_{2} \mathrm{Cl}_{2}$ under argon. To the stirred solution at $0{ }^{\circ} \mathrm{C}$ was added dimethylethylamine $(367 \mu \mathrm{L}, 3.4 \mathrm{mmol})$ followed by 2-cyanoethyl $N, N$-diisopropylchlorophosphoramidite $(166 \mu \mathrm{L}, 0.74 \mathrm{mmol})$, forming a cloudy yellow mixture that was allowed to warm to room temperature for $2 \mathrm{~h}$. Without workup, the mixture was directly loaded onto a silica gel column and eluted with 1:1 EtOAc:hexane containing $1 \% \mathrm{Et}_{3} \mathrm{~N}$, providing $0.21 \mathrm{~g}$ $(0.31 \mathrm{mmol}, 94 \%$ yield $)$ of the phosphoramidite as a yellow oil. ${ }^{1} \mathrm{H}$ NMR $\left(500 \mathrm{MHz}\right.$, acetone- $\left.\mathrm{d}_{6}\right) \delta 8.58(\mathrm{~s}$, $1 \mathrm{H}), 8.51(\mathrm{~d}, J=8.5 \mathrm{~Hz}, 2 \mathrm{H}), 8.09(\mathrm{~d}, J=8.5 \mathrm{~Hz}, 2 \mathrm{H}), 7.54(\mathrm{~m}, 4 \mathrm{H}), 5.56(\mathrm{~s}, 2 \mathrm{H}), 3.84(\mathrm{~m}, 4 \mathrm{H}), 3.56(\mathrm{~m}$, 24H), $2.74(\mathrm{~m}, 2 \mathrm{H}), 1.17(\mathrm{~m}, 12 \mathrm{H}) .{ }^{31} \mathrm{P}$ NMR $\left(202 \mathrm{MHz}\right.$, acetone-d $\left.\mathrm{d}_{6}\right) \delta 149.16 \mathrm{ppm}$. 
Selection procedure. The selection scheme is shown in Figure 1. The selection process comprised three steps:

Step 1. The initial pool $(200 \mathrm{pmol})$ in $8 \mu \mathrm{L}$ of water was mixed with $10 \mu \mathrm{L}$ of $1 \mathrm{M}$ Tris, $\mathrm{pH} 7.5,13.3$ $\mu \mathrm{L}$ of $3 \mathrm{M} \mathrm{NaCl}, 20 \mu \mathrm{L}$ of $1 \mathrm{M} \mathrm{KCl}$, and $128.7 \mu \mathrm{L}$ of water $(180 \mu \mathrm{L}$ total volume). The sample was denatured by heating to $95{ }^{\circ} \mathrm{C}$ for $4 \mathrm{~min}$ and cooling on ice for $15 \mathrm{~min}$. To the denatured sample was added $4 \mu \mathrm{L}$ of $1 \mathrm{M} \mathrm{CaCl}_{2}, 4 \mu \mathrm{L}$ of $1 \mathrm{M} \mathrm{MgCl}_{2}, 1 \mu \mathrm{L}$ of $1 \mathrm{mM} \mathrm{ZnCl}_{2}$ in $2 \mathrm{mM} \mathrm{HNO}_{3}$, and $1 \mu \mathrm{L}$ of a combined stock of $1 \mathrm{mM}$ each $\mathrm{MnCl}_{2}, \mathrm{CoCl}_{2}$, and $\mathrm{CuCl}_{2}$, followed by $9.6 \mu \mathrm{L}$ of DMSO to a total volume of 199.6 $\mu \mathrm{L}$. The reaction was initiated by the addition of $0.4 \mu \mathrm{L}$ of $50 \mathrm{mM}$ DTME (dithiobismaleimidoethane, Pierce 22335) in DMSO, making a total volume of $200 \mu \mathrm{L}$. Final concentrations were as follows: $50 \mathrm{mM}$ Tris, $\mathrm{pH} 7.5,200 \mathrm{mM} \mathrm{NaCl}, 100 \mathrm{mM} \mathrm{KCl}, 20 \mathrm{mM} \mathrm{CaCl}_{2}, 20 \mathrm{mM} \mathrm{MgCl}_{2}, 5 \mu \mathrm{M}$ each of $\mathrm{MnCl}_{2}, \mathrm{CoCl}_{2}$, $\mathrm{CuCl}_{2}$, and $\mathrm{ZnCl}_{2}, 100 \mu \mathrm{M}$ DTME, and 5\% (v/v) DMSO. The sample was incubated for $1 \mathrm{~h}$ at $30{ }^{\circ} \mathrm{C}$ and extracted with $\mathrm{CHCl}_{3}(2 \times 300 \mu \mathrm{L})$ to remove excess DTME. The sample was precipitated with $600 \mu \mathrm{L}$ of ethanol and redissolved in $8 \mu \mathrm{L}$ of water. In subsequent selection rounds, the PCR product from step 3 was treated analogously in $30 \mu \mathrm{L}$ total volume after addition of all components $(1 \mathrm{~h}$ incubation for rounds $2-10$; 5 min incubation for rounds 11-14). The sample was diluted to $200 \mu \mathrm{L}$ with $170 \mu \mathrm{L}$ of water, extracted with $\mathrm{CHCl}_{3}(2 \times 300 \mu \mathrm{L})$, precipitated with $20 \mu \mathrm{L}$ of $3 \mathrm{M} \mathrm{NaCl}$ and $600 \mu \mathrm{L}$ of ethanol, and redissolved in $8 \mu \mathrm{L}$ of water. The selection activity progression is shown in Figure $\mathrm{S} 1$; individual deoxyribozymes were cloned following round 12.

Step 2. A sample of $5^{\prime}$-thiol DNA was prepared by dissolving $1.5 \mathrm{nmol}$ of the $5^{\prime}$-disulfide precursor oligonucleotide (5'-GGATAATACGACTCAC-3' with 3'-thiol modifier 3'-O $\left(\mathrm{CH}_{2}\right)_{3} \mathrm{~S}-\mathrm{S}\left(\mathrm{CH}_{2}\right)_{3} \mathrm{OH}$, prepared at IDT) in $18 \mu \mathrm{L}$ of water and adding $6 \mu \mathrm{L}$ of water containing $250 \mathrm{mM}$ HEPES, $\mathrm{pH} 7.5$, and $750 \mathrm{mM}$ $\mathrm{NaCl}$ followed by $6 \mu \mathrm{L}$ of $250 \mathrm{mM}$ DTT. The $30-\mu \mathrm{L}$ sample was incubated at $37^{\circ} \mathrm{C}$ for $1 \mathrm{~h}$ and diluted to $180 \mu \mathrm{L}$ with $150 \mu \mathrm{L}$ of water. The 5'-thiol DNA was precipitated with $20 \mu \mathrm{L}$ of $3 \mathrm{M} \mathrm{NaCl}$ and $600 \mu \mathrm{L}$ of ethanol and redissolved in $30 \mu \mathrm{L}$ of water. To the $8-\mu \mathrm{L}$ sample from step 1 was added $2 \mu \mathrm{L}$ of $1 \mathrm{M}$ HEPES, pH 7.5 and 500 pmol of 5'-thiol DNA in $10 \mu \mathrm{L}$ of water. The sample was incubated for 30 min at room temperature and purified by $8 \%$ denaturing PAGE.

Step 3. In each selection round, the sample from step 2 was PCR-amplified in two stages. In the first stage, 10 cycles of PCR were performed in $100 \mu \mathrm{L}$ with 50 pmol of primer 1t, 200 pmol of Anthr-HEG primer 2, $0.2 \mathrm{mM}$ of each dNTP, $1 \times$ of NEB ThermoPol buffer $(20 \mathrm{mM}$ Tris-HCl, pH $8.8,10 \mathrm{mM}$ $\left(\mathrm{NH}_{4}\right)_{2} \mathrm{SO}_{4}, 10 \mathrm{mM} \mathrm{KCl}, 2 \mathrm{mM} \mathrm{MgSO} 4,0.1 \%$ Triton X-100), and 5 units of Taq polymerase (PCR conditions: $94{ }^{\circ} \mathrm{C}$ for $2 \mathrm{~min}$, then cycles of $94{ }^{\circ} \mathrm{C}$ for $30 \mathrm{~s}, 47^{\circ} \mathrm{C}$ for $30 \mathrm{~s}$, and $72{ }^{\circ} \mathrm{C}$ for $30 \mathrm{~s}$, with the final cycle continued for $5 \mathrm{~min}$ at $72{ }^{\circ} \mathrm{C}$ ). The sample was extracted once with $100 \mu \mathrm{L}$ of phenol-chloroformisoamyl alcohol (25:24:1) and then $75 \mu \mathrm{L}$ of chloroform-isoamyl alcohol (24:1). In the second stage, 25 cycles of PCR were performed in $50 \mu \mathrm{L}$ with $1 \mu \mathrm{L}$ of the 10-cycle PCR product, 25 pmol of primer 1t, 100 pmol of Anthr-HEG primer 2, $0.2 \mathrm{mM}$ of each dNTP, $\alpha-{ }^{32} \mathrm{P}-\mathrm{dCTP}, 1 \times$ NEB ThermoPol buffer, and 2.5 units of Taq polymerase (PCR conditions as above). The sample was purified by $8 \%$ denaturing PAGE, dissolved in $8 \mu \mathrm{L}$ of water, and taken to step 1 of the next selection round.

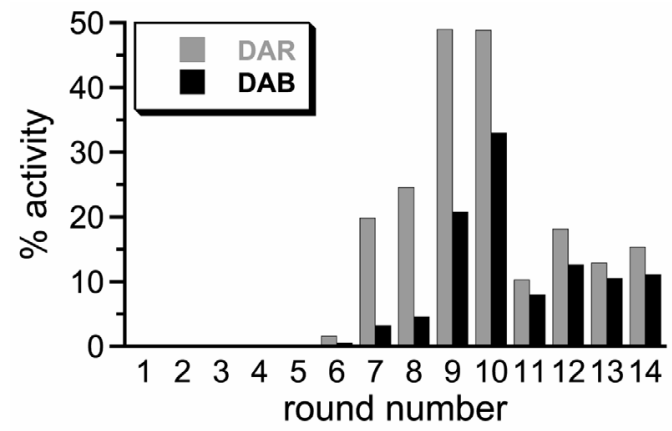

Figure S1. Selection activity progression for DAR and DAB selections. The incubation time during step 1 of the procedure was $1 \mathrm{~h}$ for rounds $1-10$ and 5 min for rounds $11-14$. Both selections were cloned from round 12 . 
Cloning and activity assays of individual Diels-Alder deoxyribozymes

Cloning and preliminary kinetic assay of deoxyribozymes. After 12 selection rounds, the 25-cycle PCR procedure of selection step 3 was performed, with the following changes: $1 \mu \mathrm{L}$ of a 1/1000 dilution of the 10-cycle PCR product was used as template; $\alpha-{ }^{32} \mathrm{P}-\mathrm{dCTP}$ was omitted; primer $1 \mathrm{t}$ was replaced with cloning primer 1c (5'-TAATTAATTAATTACCCATCAGGATCAGCT-3'); primer 2 was replaced with cloning primer 2c (5'-TAATTAATTAATTAGGAGCTCGCTTGTCG-3'). For both primers $1 \mathrm{c}$ and 2c, the $5^{\prime}-$ region contained TAA stop codons in each of the three reading frames to reduce false negatives during screening. ${ }^{7}$ The $100 \mathrm{bp}$ double-stranded DNA product (with single adenosine overhangs added by Taq polymerase) was isolated by $2 \%$ agarose gel electrophoresis (QIAquick extraction, Qiagen). Individual deoxyribozymes were cloned into E. coli using a TOPO TA cloning kit (Invitrogen). Miniprep DNA was prepared, and the presence of the expected deoxyribozyme insert was verified by EcoRI digestion and 2\% agarose gel electrophoresis. The catalytic activities of individual clones were determined in preliminary fashion via the in cis kinetic assay described below, using deoxyribozyme strands generated by PCR and purified by PAGE as described in selection step 3 (1 $\mu \mathrm{L}$ of a 1/10 dilution of miniprep DNA was used as template, with total PCR volume $15 \mu \mathrm{L}$ ). Out of 16 DAR clones, all were active (all but one clone $>40 \%$ yield at $1 \mathrm{~h}$, and 9 clones $>75 \%$ yield at $1 \mathrm{~h}$ ). Out of $17 \mathrm{DAB}$ clones assayed, all but two were active (of the remaining 15 clones, all but one clone $>45 \%$ yield at $1 \mathrm{~h}$, and 1 clone $>75 \%$ yield at $1 \mathrm{~h}$ ). Automated sequencing of the most catalytically active clones was performed at the UIUC Biotechnology Center, with sequences and yields in Table S1. Only minimal homology was observed between any of the sequences.

\section{Table S1}

\begin{tabular}{|c|c|c|c|}
\hline$\underline{\text { clone }}$ & \% yield $^{b}$ & \% yield ${ }^{c}$ & $\underline{\text { sequence }}^{a}$ \\
\hline DAR2 & 78 & 68 & AGGTGAGCCGTATTAтTCAAGGTGTTACTAGGCGGGAGTT \\
\hline DAR3 & 81 & 63 & AGGGGAGTGAGTCGCTAGCATGATAGATGAACGGGGGTGA \\
\hline DAR4 & 81 & n.d. & GACCAATGCGAGGTGAGTCGTTCCAACCACGATGGGAGTG \\
\hline DAR10 & 84 & n.d. & AGGGGAGTGAGTCGCAAGCATGATAGATGAACGGGGGTG \\
\hline DAR12 & 74 & n.d. & AGGGGAGTCGTAATTATTCGAACGGGGGTG \\
\hline DAR14 & 53 & 56 & CATTAGCGACAGGGTGTTGGGGTGGGTGTATTATCGGGAT \\
\hline DAR17 & 78 & 68 & GGGCGAGGTGAGCCGTGAAAGAATATTATAGGCGGGAGTG \\
\hline DAR22 & 52 & 52 & GTCGAATTATCCAGTATGAACGACGGGAACGGGGTGGGCT \\
\hline DAR23 & 40 & 46 & TAGGTGAGACGGATTAGCTACGTAAAAATCCGCGGGAGTG \\
\hline DAR24 & 90 & 72 & GACCAATGCGAGGTGAGTCGTTTTAACCACGACGGGAGTT \\
\hline DAB5 & 50 & 23 & TCGAAGCGGTTCCAGTAAGTCGTAGTAAGTCTCGTC \\
\hline DAB6 & 55 & 57 & ACGAGGAATACTCGTTGACGGGAGTAGGGGTGGGG \\
\hline DAB7 & 45 & 34 & AGGGGGATGTTCGGATTGTCCGGGGAATACCTAGG \\
\hline DAB8 & 61 & n.d. & AGGGGGATGTTCGGATTGTCCGGGGAATACTAGCC \\
\hline DAB 9 & 60 & n.d. & ACGAGGAATACTCGTTGACGGGAGTAGGGGTGGGG \\
\hline DAB10 & 54 & 54 & CAGAGGCTGTGACGGGACTTGGGGGTGGGAGTCGTT \\
\hline DAB12 & 69 & 60 & TCAAGACAGGGCAAGGGGTGGGGTCGAATGATCAAT \\
\hline DAB13 & 70 & n.d. & TCAAGACAGGGCAAGGGGTGGGGTCGAATGATCAAT \\
\hline DAB18 & 66 & 27 & ACTGGGTCGTATTACCTTTTGAGGGCAACCCCCCGA \\
\hline DAB19 & 56 & n.d. & TCAAGACAGGGCAAGGGGTGGGGTCGAATGATCAAT \\
\hline DAB20 & 47 & 43 & GGCGAGGTGAGGCGACCTCATAGGAGCGGGAGTGGGC \\
\hline DAB22 & 86 & 66 & GTGAGCTCGTGGCAGGTCGTAGGTGCAAGCCCCCAC \\
\hline DAB23 & 68 & n.d. & ACGAGGAATACTCGTTGACGGGAGTAGGGGTGGGG \\
\hline DAB24 & 50 & 41 & GTCAGACAGGGACAGGGGTGGGGAGCATTATTCGTC \\
\hline
\end{tabular}

${ }^{a}$ All sequences are written in the $5^{\prime}$ to $3^{\prime}$ direction. Only the originally random region is shown; each sequence is preceded by 5'-GGAGCTCGCTTGTCG... and followed by ...AGCTGATCCTGATGG-3'.

${ }^{b}$ Yield at $1 \mathrm{~h}$ in the in cis kinetic assay for the deoxyribozyme prepared by PCR from miniprep DNA.

${ }^{c}$ Yield at $1 \mathrm{~h}$ in the in cis kinetic assay for the deoxyribozyme prepared by PCR from a template made by solidphase synthesis. n.d. = not determined (generally because sequence was similar to another already being tested). 
Catalytic activities of individual deoxyribozymes. The catalytic activities of most individual deoxyribozymes were re-surveyed using PCR templates prepared by solid-phase synthesis; we consider this to be more reproducible than using miniprep DNA as the PCR template. The PCR templates were prepared in the forward (coding) direction. The deoxyribozymes were generated using the 25-cycle PCR procedure of selection step 3 in $25 \mu \mathrm{L}$ volume. Each PAGE-purified deoxyribozyme was assayed via the in cis kinetic assay described below, with data in Table S1.

\section{Additional activity assays of individual Diels-Alder deoxyribozymes}

The mfold program ${ }^{8}$ was used to generate secondary structure predictions for each deoxyribozyme of Table S1. In each case, a stem-loop secondary structure element was predicted to form near the 5'-end of the deoxyribozyme (stem length 4-8 bp). We determined experimentally if the loops of these putative stem-loop elements could be divided such that the deoxyribozyme could be reconstituted using a "substrate" strand representing Anthr-HEG attached to the 5'-portion of the DNA and an "enzyme" strand representing the 3'-portion of the DNA. This division is illustrated in Figure S6 below for the DAB22 deoxyribozyme (in the section on "Testing secondary structure"). The 12-nt Anthr-HEG substrate oligonucleotide was prepared by solid-phase synthesis using the Anthr-HEG phosphoramidite and subsequently $3^{\prime}-{ }^{32} \mathrm{P}$-radiolabeled using $\alpha-{ }^{32} \mathrm{P}$-dCTP and terminal deoxytransferase (TdT; NEB) using the following procedure. To $50 \mathrm{pmol}$ of Anthr-HEG oligonucleotide in $38.2 \mu \mathrm{L}$ of water was added $5 \mu \mathrm{L}$ of $2.5 \mathrm{mM} \mathrm{CoCl}_{2}, 5 \mu \mathrm{L}$ of $10 \times$ NEB buffer $4(10 \times$ buffer is $20 \mathrm{mM}$ Tris-acetate, $\mathrm{pH} 7.9,50 \mathrm{mM} \mathrm{KOAc}, 10$ $\mathrm{mM} \mathrm{Mg}(\mathrm{OAc})_{2}, 1 \mathrm{mM}$ DTT $), 1.3 \mu \mathrm{L} \alpha-{ }^{32} \mathrm{P}-\mathrm{dCTP}$, and $0.5 \mu \mathrm{L}$ TdT $(20$ units $/ \mu \mathrm{L})$. The sample was incubated for $40 \mathrm{~min}$ at $37{ }^{\circ} \mathrm{C}$ and purified by $20 \%$ denaturing PAGE. Activity assays were performed as follows. A sample containing $1 \mathrm{pmol}$ of $3^{\prime}-{ }^{32} \mathrm{P}$-labeled substrate strand and $15 \mathrm{pmol}$ of enzyme strand was annealed in $0.75 \mu \mathrm{L}$ of $1 \mathrm{M}$ Tris, $\mathrm{pH} 7.5,1 \mu \mathrm{L}$ of $3 \mathrm{M} \mathrm{NaCl}, 1.5 \mu \mathrm{L}$ of $1 \mathrm{M} \mathrm{KCl}$ and $3.5 \mu \mathrm{L}$ of water by heating at $95{ }^{\circ} \mathrm{C}$ for $4 \mathrm{~min}$ and cooling at room temperature for $15 \mathrm{~min}$. To the sample was added $3 \mu \mathrm{L}$ of $1 \mathrm{M} \mathrm{MgCl}_{2}, 3 \mu \mathrm{L}$ of $1 \mathrm{M} \mathrm{CaCl}_{2}, 0.75 \mu \mathrm{L}$ of $0.1 \mathrm{mM} \mathrm{ZnCl}_{2}$ in $0.2 \mathrm{mM} \mathrm{HNO}_{3}$, and $0.75 \mu \mathrm{L}$ of a combined stock of $0.1 \mathrm{mM}$ of each of $\mathrm{MnCl}_{2}, \mathrm{CoCl}_{2}$, and $\mathrm{CuCl}_{2}$, followed by $0.45 \mu \mathrm{L}$ of DMSO to a total volume of $14.7 \mu \mathrm{L}$. The reaction was initiated by the addition of $0.3 \mu \mathrm{L}$ of $5 \mathrm{mM}$ DTME in DMSO, making a total volume of $15 \mu \mathrm{L}$. Final concentrations were as follows: $50 \mathrm{mM}$ Tris, $\mathrm{pH} 7.5,200 \mathrm{mM} \mathrm{NaCl}, 100 \mathrm{mM}$ $\mathrm{KCl}, 20 \mathrm{mM} \mathrm{MgCl} 2,20 \mathrm{mM} \mathrm{CaCl} 2,5 \mu \mathrm{M}$ each of $\mathrm{MnCl}_{2}, \mathrm{CoCl}_{2}, \mathrm{CuCl}_{2}$, and $\mathrm{ZnCl}_{2}, 67 \mathrm{nM}$ substrate strand, $1 \mu \mathrm{M}$ enzyme strand, $100 \mu \mathrm{M}$ DTME, and $5 \%(\mathrm{v} / \mathrm{v}) \mathrm{DMSO}$. The sample was incubated at $30{ }^{\circ} \mathrm{C} ; 2$ $\mu \mathrm{L}$ aliquots were removed at appropriate timepoints and quenched into $2 \mu \mathrm{L}$ of $250 \mathrm{mM}$ DTT (this suppressed any further reaction of DTME and also led to cleaner bands, presumably due to resolving minor amounts of disulfide interchange products). The samples were analyzed on $20 \%$ denaturing PAGE. Of the 7 DAR deoxyribozymes and 9 DAB deoxyribozymes that were assayed by this procedure (all of which have two yield entries in Table S1), only DAB22 was active $(>5 \%)$ in the divided format.

The same deoxyribozymes were also assayed with the enzyme portion intact but with Anthr-HEG provided as a separate small molecule (i.e., not attached to the 5'-terminus of the DNA). These experiments were performed using the in trans kinetic assay described below. Again, only DAB22 showed substantial Diels-Alder activity in this assay ( $40 \%$ yield in 15 min under the assay conditions); all of the other deoxyribozymes had $<8 \%$ yield in $15 \mathrm{~min}$. Note that the background rate in trans is rather high, as described below ( $\sim 3 \%$ yield in $15 \mathrm{~min})$.

\section{In cis kinetic assays of the DAB22 deoxyribozyme}

The DAB22 deoxyribozyme was generated using the 25-cycle PCR procedure of selection step 3 in $50 \mu \mathrm{L}$ volume, using a forward (coding) template prepared by solid-phase synthesis. The desired deoxyribozyme strand was purified by $8 \%$ denaturing PAGE. We estimate that $\sim 25$ pmol of the internally ${ }^{32} \mathrm{P}$-radiolabeled deoxyribozyme strand was isolated. Half of this sample was annealed in $1.25 \mu \mathrm{L}$ of $1 \mathrm{M}$ Tris, $\mathrm{pH} 7.5$, and $22 \mu \mathrm{L}$ of water by heating at $95{ }^{\circ} \mathrm{C}$ for $4 \mathrm{~min}$ and cooling on ice for $15 \mathrm{~min}$. To the sample was added 0.5 $\mu \mathrm{L}$ of $1 \mathrm{M} \mathrm{CaCl}_{2}$, followed by $1 \mu \mathrm{L}$ of DMSO to a total volume of $24.75 \mu \mathrm{L}$. The reaction was initiated by the addition of $0.25 \mu \mathrm{L}$ of $5 \mathrm{mM}$ DTME in DMSO, making a total volume of $25 \mu \mathrm{L}$. Final concentrations were as follows: $50 \mathrm{mM}$ Tris, $\mathrm{pH} 7.5,20 \mathrm{mM} \mathrm{CaCl}_{2}, \sim 0.5 \mu \mathrm{M}$ deoxyribozyme, $50 \mu \mathrm{M}$ DTME, and $5 \%$ 
(v/v) DMSO. The sample was incubated at $23{ }^{\circ} \mathrm{C} ; 1.5 \mu \mathrm{L}$ aliquots were removed at appropriate timepoints and quenched into $4 \mu \mathrm{L}$ of stop solution [ $80 \%$ formamide, $1 \times$ TBE, $50 \mathrm{mM}$ EDTA, $0.025 \%$ bromophenol blue, $0.025 \%$ xylene cyanol]. The samples were analyzed on $8 \%$ denaturing PAGE. A similar $k_{\text {obs }}$ value was found when anthracene was covalently attached to the DNA (in cis) but the deoxyribozyme was present in two fragments, representing cleavage within a predicted stem-loop (see "Rate enhancement" section below).

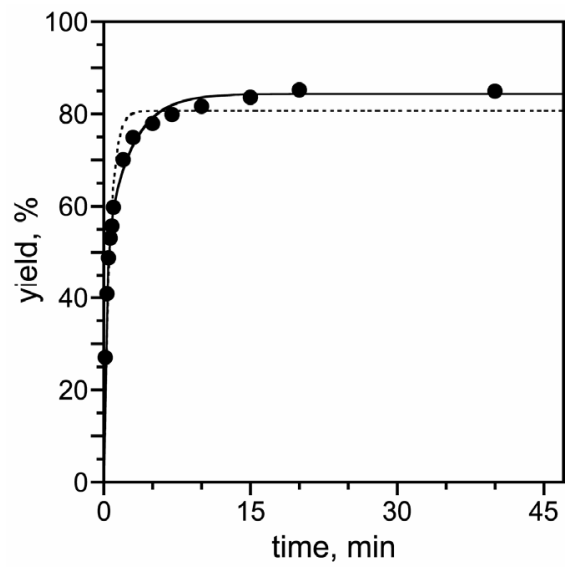

Figure S2. Determination of $k_{\mathrm{obs}}$ for the DAB22 deoxyribozyme in cis. The data set was fit to a single exponential (dotted line) or a double exponential (solid line); the double exponential clearly fit better. Curve fit parameters: single exponential $1.7 \mathrm{~min}^{-1}$ (81\% yield); double exponential $4.0 \mathrm{~min}^{-1}(49 \%)$ and $0.38 \mathrm{~min}^{-1}(35 \%)$.

In trans kinetic assays of the DAB22 deoxyribozyme

The Diels-Alder reaction between the two small molecules Anthr-HEG and DTME was monitored by UV absorbance as reported by Jäschke. ${ }^{3,9}$ The decrease in absorbance at $\lambda=386 \mathrm{~nm}\left(\mathrm{~A}_{386}\right)$ was equated to formation of product; see next section for verification of product identity by mass spectrometry. (Jäschke used $\mathrm{A}_{365}$, but DTME has an absorbance shoulder at $\sim 300 \mathrm{~nm}$ that extends near $400 \mathrm{~nm}$, making it preferable for us to use the highest possible absorbance peak for measurements.) The initial velocity $V_{\text {init }}$ was determined from the slope of the line fitted to product concentration versus time, with representative data in Figure S3. The product concentration was determined using a $75-\mu \mathrm{L}$ sample containing $10 \mu \mathrm{M}$ DAB22 deoxyribozyme, $100 \mu \mathrm{M}$ Anthr-HEG, and $500 \mu \mathrm{M}$ DTME in $50 \mathrm{mM}$ Tris, $\mathrm{pH} 7.5,20 \mathrm{mM} \mathrm{CaCl}_{2}$, and $2.5 \%(\mathrm{v} / \mathrm{v}) \mathrm{DMSO}$ at $23{ }^{\circ} \mathrm{C}$ (the concentrations of Anthr-HEG and DTME were varied in some experiments as noted). For example, if the $\mathrm{A}_{386}$ decreased by $20 \%$ at a certain timepoint relative to the initial $\mathrm{A}_{386}$, then the product concentration was computed as $20 \% \times 100 \mu \mathrm{M}=20 \mu \mathrm{M}$ at that timepoint. The $k_{\text {app }}$ values were determined from $V_{\text {init }}$ according to $V_{\text {init }}=k_{\text {app }} \cdot[$ Anthr-HEG] $\bullet[D T M E]$.
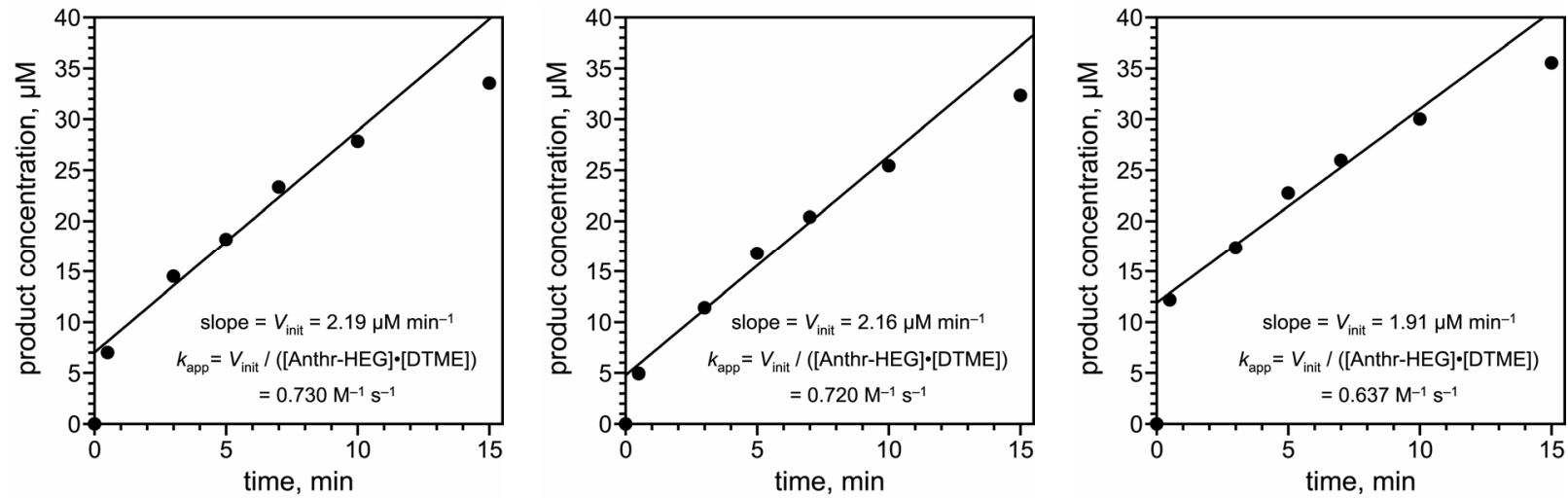

Figure S3. Kinetic plots for in trans kinetic assays of the DAB22 deoxyribozyme. Shown are representative plots from three independent experiments (UV spectra for the second experiment are shown in Figure 2). The extent of the vertical offset of the fit line (i.e., the y-intercept) is not reproducible and appears to reflect an artifact due to background subtraction. In contrast, the slope of the fit line $\left(=V_{\text {init }}\right)$ is reproducible within reasonable error. 
ESI-MS to verify the in trans DAB22 reaction product identity

Formation of the expected Diels-Alder adduct from the reaction between the two small molecules AnthrHEG and DTME was verified by electrospray ionization mass spectrometry (ESI-MS). A 75- $\mu \mathrm{L}$ sample containing $10 \mu \mathrm{M}$ DAB22 deoxyribozyme, $100 \mu \mathrm{M}$ Anthr-HEG, and $500 \mu \mathrm{M}$ DTME in $50 \mathrm{mM}$ Tris, $\mathrm{pH}$ 7.5, $20 \mathrm{mM} \mathrm{CaCl} 2$, and 2.5\% (v/v) DMSO was incubated for $20 \mathrm{~min}$ at $23{ }^{\circ} \mathrm{C}$. After $20 \mathrm{~min}$, UV absorbance $\left(\mathrm{A}_{386}\right)$ indicated that $\sim 40 \%$ of the anthracene was consumed. The reaction was optionally quenched by addition of $1.5 \mu \mathrm{L}$ of $250 \mathrm{mM}$ DTT (final DTT concentration $5 \mathrm{mM}$ ). The sample was extracted with $2 \times 100 \mu \mathrm{L} \mathrm{CHCl}_{3}$, and the $\mathrm{CHCl}_{3}$ extracts were directly analyzed by ESI-MS. With DTT quench, calcd. for $\mathrm{C}_{33} \mathrm{H}_{43} \mathrm{NO}_{9} \mathrm{SNa}[\mathrm{M}+\mathrm{Na}]^{+}$652.76; found 652.4 (Figure S4). Without DTT quench, calcd. for $\mathrm{C}_{39} \mathrm{H}_{49} \mathrm{~N}_{2} \mathrm{O}_{11} \mathrm{~S}_{2}[\mathrm{M}+\mathrm{H}]^{+}$785.96; found 785.5.

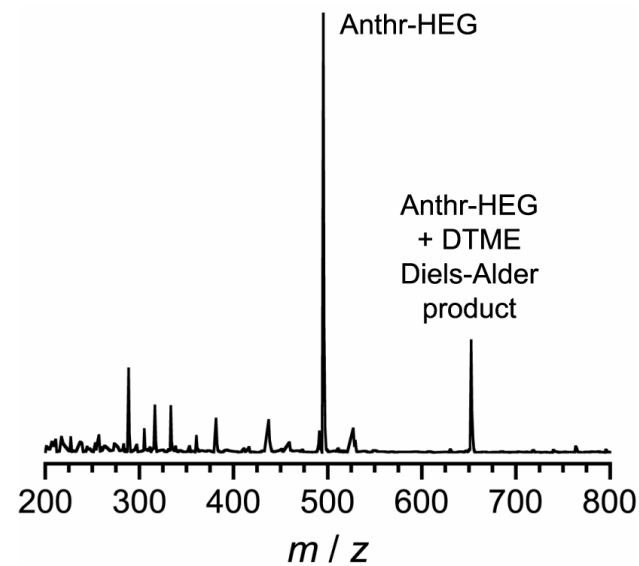

Figure S4. ESI mass spectrum of the crude reaction product between Anthr-HEG and DTME as catalyzed by the DAB22 deoxyribozyme (after quenching with DTT, which reduces the disulfide linkage within DTME). As expected, both unreacted Anthr-HEG (calcd. for $\mathrm{C}_{27} \mathrm{H}_{36} \mathrm{O}_{7} \mathrm{Na}[\mathrm{M}+\mathrm{Na}]^{+}$495.57; found 495.4) and the anticipated Diels-Alder adduct are observed.

\section{Determination of $K_{\text {d,app }}$ for $\mathrm{Ca}^{2+}$ for DAB22 in trans}

The dependence of $k_{\text {app }}$ (in trans) on $\mathrm{Ca}^{2+}$ concentration was used to determine $K_{\text {d,app }}$ for $\mathrm{Ca}^{2+}$ for the DAB22 deoxyribozyme (Figure S5). The data were obtained and analyzed using the standard conditions described above. From the curve fit, $K_{\text {d,app }}$ was estimated as $5.5 \pm 0.6 \mathrm{mM}$.

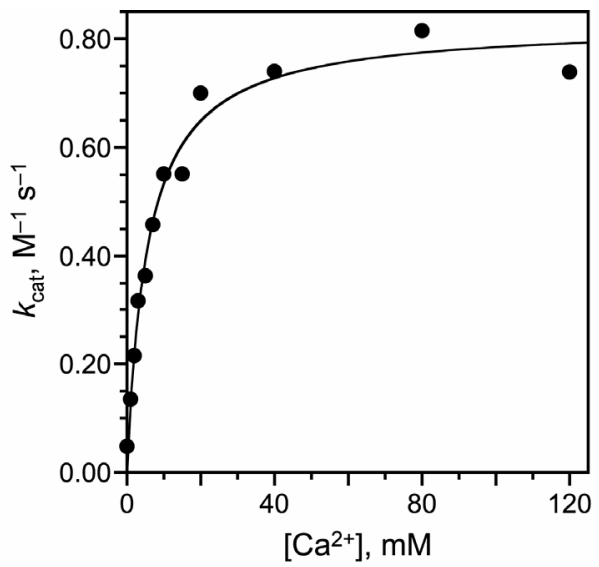

Figure S5. Determination of $K_{\mathrm{d}, \mathrm{app}}$ for $\mathrm{Ca}^{2+}$ for the DAB22 deoxyribozyme in trans. The data were not corrected for the relatively small $k_{\text {app }}$ observed at zero $\mathrm{Ca}^{2+}$ (i.e., $k_{\text {uncat }}\left[+\mathrm{DNA},-\mathrm{Ca}^{2+}\right.$, which was $0.048 \pm 0.002 \mathrm{M}^{-1} \mathrm{~s}^{-1}[\mathrm{n}=2]$ ), in part because it is unclear if this zero- $\mathrm{Ca}^{2+} k_{\text {app }}$ is the best measure of $k_{\text {uncat }}$. See the "Rate enhancement" section below for a more complete discussion of $k_{\text {app }}$ and $k_{\text {uncat }}$. If the data are corrected for the $k_{\text {app }}$ observed at zero $\mathrm{Ca}^{2+}$, then $K_{\text {d,app }}$ is $6.6 \pm 0.8 \mathrm{mM}$, which is not substantially different from the uncorrected $K_{\text {d,app }}$ value. 
Dependence of the DAB22 deoxyribozyme on metal ion identity

The dependence of DAB22 on metal ion identity was examined in trans, using kinetic assays analogous to those described above. All metals were provided as their $\mathrm{Cl}^{-}$salts. In separate data acquired in parallel, 20 $\mathrm{mM} \mathrm{Mg}{ }^{2+}\left(k_{\text {app }}=0.47 \mathrm{M}^{-1} \mathrm{~s}^{-1}\right)$ was found to be nearly as effective as $20 \mathrm{mM} \mathrm{Ca}{ }^{2+}\left(0.65 \mathrm{M}^{-1} \mathrm{~s}^{-1}\right)$. Similarly, $5 \mathrm{mM} \mathrm{Mn}^{2+}\left(0.38 \mathrm{M}^{-1} \mathrm{~s}^{-1}\right)$ was as effective as $5 \mathrm{mM} \mathrm{Ca}^{2+}\left(0.32 \mathrm{M}^{-1} \mathrm{~s}^{-1}\right)$. At higher $\left[\mathrm{Mn}^{2+}\right]$ a slightly turbid solution was observed; therefore, the $k_{\text {app }}$ value at $20 \mathrm{mM} \mathrm{Mn}^{2+}$ was considered to be unreliable. In contrast to the findings with $\mathrm{Ca}^{2+}, \mathrm{Mg}^{2+}$, and $\mathrm{Mn}^{2+}$, each of $\mathrm{Co}^{2+}, \mathrm{Cu}^{2+}$, and $\mathrm{Zn}^{2+}$ at $5 \mu \mathrm{M}$ (as was used during selection) individually provided $k_{\text {app }}$ values that were indistinguishable from background (i.e., $k_{\text {app }}$ in the absence of all added metal ions $=k_{\text {uncat }}$ ). In addition, none of $\mathrm{Co}^{2+}, \mathrm{Cu}^{2+}$, and $\mathrm{Zn}^{2+}$ at $5 \mu \mathrm{M}$ increased $k_{\text {app }}$ for $20 \mathrm{mM} \mathrm{Ca}^{2+}$. In assays of monovalent metal ion dependence, inclusion of either $200 \mathrm{mM}$ $\mathrm{Na}^{+}, 100 \mathrm{mM} \mathrm{K}$, or both along with $20 \mathrm{mM} \mathrm{Ca}^{2+}$ had little effect on $k_{\text {app }}: 0.50,0.60$, and $0.52 \mathrm{M}^{-1} \mathrm{~s}^{-1}$, respectively.

The dependence of DAB22 on metal ion identity was also briefly examined in cis. Each of $5 \mu \mathrm{M} \mathrm{Co}^{2+}$, $\mathrm{Cu}^{2+}$, and $\mathrm{Zn}^{2+}$ led to no activity above background, and neither $\mathrm{Na}^{+}$nor $\mathrm{K}^{+}$had any substantial effect on the activity with $20 \mathrm{mM} \mathrm{Ca}^{2+}$. These were similar to the observations in trans.

Testing the secondary structure of the DAB22 deoxyribozyme

We used the mfold program ${ }^{8}$ to generate predicted secondary structures of the DAB22 deoxyribozyme. In all of the low-energy predicted secondary structures, the 5'-terminus consisted of an 8-bp stem with a 6-nt loop designated "stem I" (Figure S6). In addition, various other stem or stem-loop elements were present in each individual structure. Experimentally, we first examined stem I. Conceptual cleavage within the 6nt loop (as marked in Figure S6) created a 12-nt 5'-Anthr-HEG substrate strand (5'-GGAGCTCGCTTG-3') and a 51-nt enzyme strand (the three 5'-terminal nucleotides 5'-TCG were omitted), leaving intact the 8-bp stem I (enzyme strand: 5'-GTGAGCTC...). The 8-bp stem I regions are underlined; note that there is a single $\mathrm{G} \bullet \mathrm{T}$ wobble pair at the second position counting forward from the $5^{\prime}$-terminus of the enzyme strand. A series of shortened enzyme strands was prepared, each successively omitting one additional nucleotide from the $5^{\prime}$-terminus and therefore leaving stem I as short as $3 \mathrm{bp}$. Each of these enzyme strands was tested with the 12-nt substrate strand as described in the section above on "Additional activity assays". The reaction yield in $1 \mathrm{~h}$ as a function of stem I length was as follows: $8 \mathrm{bp}, 85 \% ; 7 \mathrm{bp}, 85 \% ; 6 \mathrm{bp}, 85 \% ; 5$ bp, 15\%, 4 bp, 12\%, 3 bp, 9\% (Figure S7). Furthermore, a 51-mer enzyme strand but with the stem I portion scrambled (5'-TGCTCGAG...) was poorly active $(6 \%$ in $1 \mathrm{~h})$. We then examined lengthening stem I to $11 \mathrm{bp}$ via a 54-nt enzyme strand with restored 5'-TCG. The lengthened stem I led to a 15-fold increase in rate constant ( $k_{\text {obs }}$ for 8 -bp stem I $\sim 0.2 \mathrm{~min}^{-1} ; k_{\text {obs }}$ for 11 -bp stem I $\sim 3 \mathrm{~min}^{-1}$ ). From all of these data, we conclude that the stem I element common to all of the predicted secondary structures of Figure S6 is indeed present in the active form of the DAB22 deoxyribozyme. 

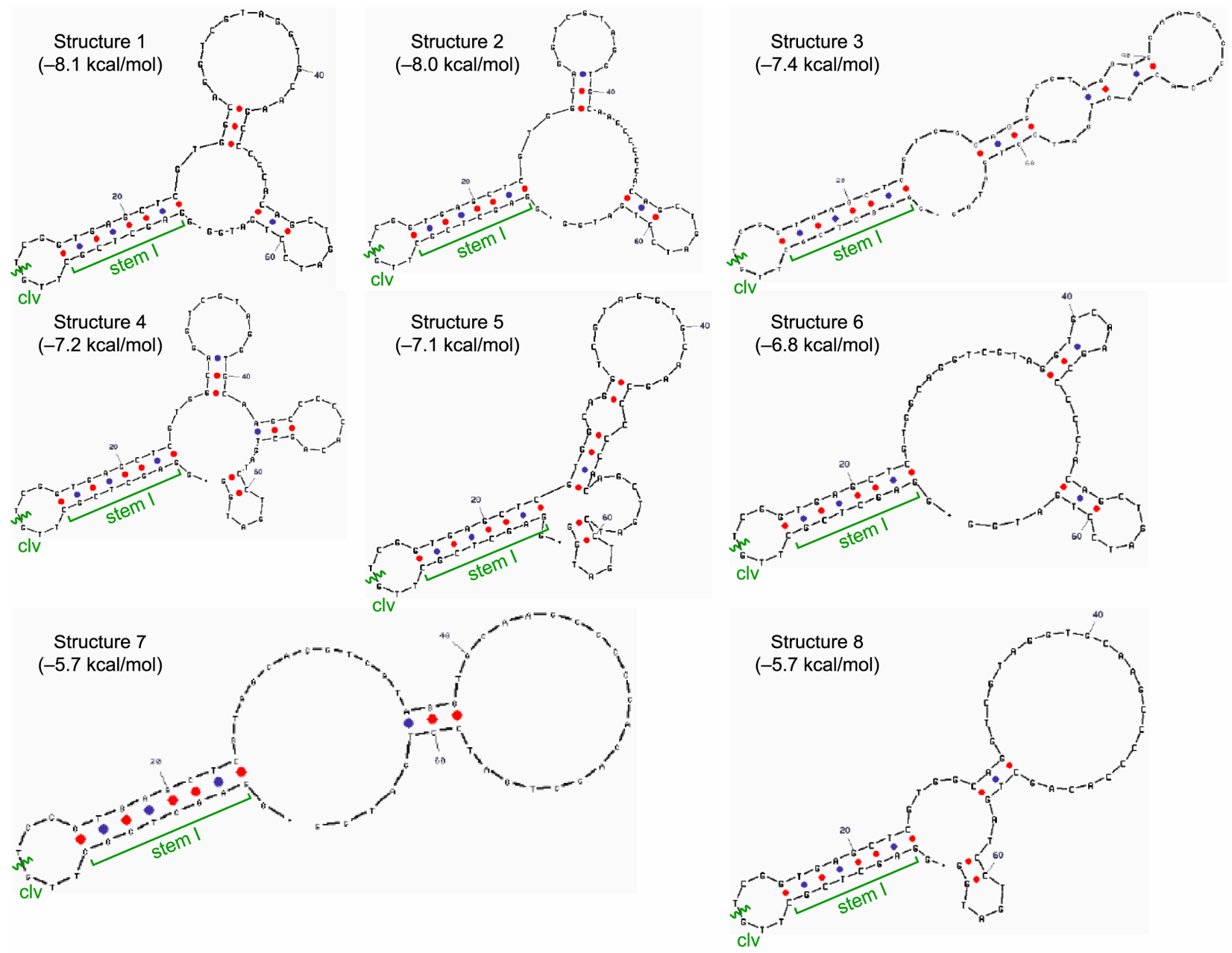

Figure S6. Mfold-predicted secondary structures for the DAB22 deoxyribozyme, generated via the mfold server. ${ }^{8}$ The 8-bp stem I (marked) is common to all of these low-energy secondary structures. In addition, various other stem and stem-loop elements are present in each structure. The site of conceptual cleavage into the 12-nt substrate strand and the 51-nt enzyme strand (after removal of 5'-TCG from the enzyme strand) is indicated on each structure with a wavy line (clv). When stem I was tested with $11 \mathrm{bp}$, the 5'-TCG was included on the 54-nt enzyme strand, thereby fully complementing the $113^{\prime}$-terminal nucleotides of the substrate strand.

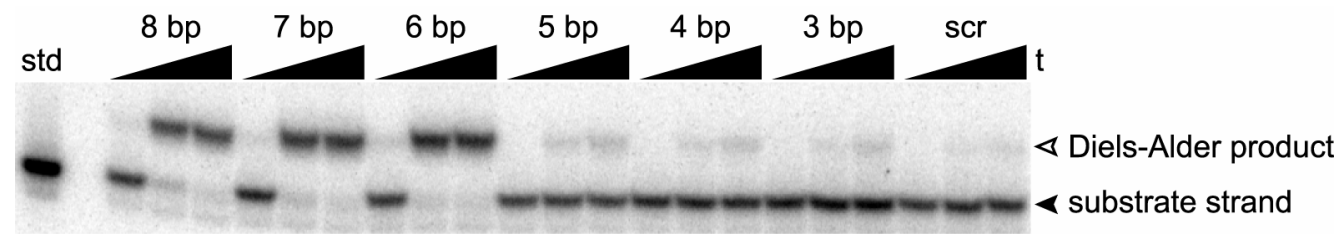

Figure S7. Evaluation of the stem I element of the DAB22 deoxyribozyme by progressively shortening the enzyme strand from its 5 -terminus. The resulting length of stem I is shown above each set of lanes $(\mathrm{t}=0.5,30,60 \mathrm{~min})$. The far right set of lanes shows the assay with the enzyme strand scrambled in the stem I region. Sequences and yields are given in the text.

We also examined the other stems that are present within individual structures of Figure S5. This was done using point mutants that individually should destabilize a given stem element and therefore disrupt catalysis, but pairwise should restore activity if the mere presence of a Watson-Crick base pair were important (without regard to nucleotide identity). In all cases we found no evidence in support of any particular stem element. These type of data inherently cannot rule out the presence of one or more of the predicted stem elements in the active deoxyribozyme, because it is possible that such a stem requires particular nucleotides and therefore cannot be revealed by this compensatory mutation analysis. 
$\underline{\text { Rate enhancements for the DAB22 deoxyribozyme and 39M49 ribozyme }}$

Because a central goal of this study was to determine the relative catalytic efficiencies of Diels-Alder deoxyribozymes and ribozymes, we carefully determined the rate enhancements for DAB22 and 39M49. In the case of 39M49, we felt it was most appropriate for us to redetermine the rate enhancement values independently of the values reported previously by Jäschke and coworkers, so that our comparisons between the DNA and RNA values would be reasonable. For both DAB22 and 39M49 the rate enhancement (RE) values were determined both with anthracene as part of the free substrate molecule Anthr-HEG (in trans) or with anthracene attached covalently to the DNA (in cis).

For anthracene in trans and DAB22, using DTME as dienophile and UV absorbance measurements (e.g., Figure 2, and see also the section below on Michaelis-Menten parameters), we found $k_{\text {app }}=0.70 \pm 0.05 \mathrm{M}^{-1} \mathrm{~s}^{-1}(\mathrm{n}=3)$ using the standard deoxyribozyme conditions of $100 \mu \mathrm{M}$ Anthr-HEG, $500 \mu \mathrm{M}$ DTME, $10 \mu \mathrm{M}$ deoxyribozyme, $50 \mathrm{mM}$ Tris, $\mathrm{pH}$ 7.5, $20 \mathrm{mM} \mathrm{CaCl}_{2}$, and $2 \% \mathrm{DMSO}$ at $23{ }^{\circ} \mathrm{C}$. The value of $k_{\text {uncat }}$ in the absence of DNA and presence of $\mathrm{Ca}^{2+}$ was $0.056 \pm 0.001 \mathrm{M}^{-1} \mathrm{~s}^{-1}(\mathrm{n}=2)$. The value of $k_{\text {uncat }}$ in the presence of DNA and absence of $\mathrm{Ca}^{2+}$ was $0.048 \pm 0.002 \mathrm{M}^{-1} \mathrm{~s}^{-1}(\mathrm{n}=2)$, as indicated in the section above on metal dependence. The $k_{\text {uncat }}$ values were determined using timepoints up to $4 \mathrm{~h}$. The RE calculated using the higher $k_{\text {uncat }}$ value (which leads to a more conservative estimate of RE) was $0.70 / 0.056=13$.

For anthracene in trans and 39M49, Jaschke reported a RE of 92 using $N$-pentylmaleimide (NPM) as the dienophile. ${ }^{10}$ This value was derived from $k_{\text {app }}=1.1 \mathrm{M}^{-1} \mathrm{~s}^{-1}$ and $k_{\text {uncat }}=0.012 \mathrm{M}^{-1} \mathrm{~s}^{-1}$, both of which they determined by UV absorbance measurements under their standard conditions of $100 \mu \mathrm{M}$ Anthr-HEG, $500 \mu \mathrm{M}$ NPM, $7 \mu \mathrm{M}$ ribozyme, $30 \mathrm{mM}$ Tris, $\mathrm{pH} 7.4,80 \mathrm{mM} \mathrm{MgCl}_{2}$, and $10 \%$ ethanol at $24{ }^{\circ} \mathrm{C}$. Their $k_{\text {uncat }}$ was determined in the absence of RNA and presence of $\mathrm{Mg}^{2+}$. We determined the RE for 39M49 using UV absorbance and either NPM or (separately) DTME as dienophile (see representative UV data in section below on Michaelis-Menten parameters). For NPM, we found $k_{\text {app }}=0.81 \pm 0.02 \mathrm{M}^{-1} \mathrm{~s}^{-1}(\mathrm{n}=2)$ and $k_{\text {uncat }}=0.033 \pm 0.001 \mathrm{M}^{-1} \mathrm{~s}^{-1}(\mathrm{n}=2)$ under our standard ribozyme conditions of $100 \mu \mathrm{M}$ AnthrHEG, $500 \mu \mathrm{M}$ NPM, $10 \mu \mathrm{M}$ ribozyme, $30 \mathrm{mM}$ Tris, $\mathrm{pH} 7.5,80 \mathrm{mM} \mathrm{MgCl}_{2}$, and $2 \% \mathrm{DMSO}$ at $23{ }^{\circ} \mathrm{C}$, which are very similar to Jäschke's conditions (replacing $10 \%$ ethanol with $2 \%$ DMSO; in other

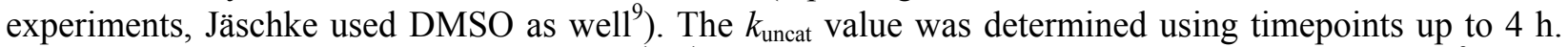
We found the same $k_{\text {uncat }}$ value $\left( \pm 0.001 \mathrm{M}^{-1} \mathrm{~s}^{-1}\right)$ either in the absence of RNA and presence of $\mathrm{Mg}^{2+}$ or in the presence of RNA and absence of $\mathrm{Mg}^{2+}$. From these $k_{\text {app }}$ and $k_{\text {uncat }}$ values, we calculated RE of $0.81 / 0.033=25$. Via analogous measurements using DTME as dienophile, we found $k_{\text {app }}=0.72 \pm 0.05 \mathrm{M}^{-}$ ${ }^{1} \mathrm{~s}^{-1}(\mathrm{n}=2)$ and $k_{\text {uncat }}=0.049 \pm 0.003 \mathrm{M}^{-1} \mathrm{~s}^{-1}(\mathrm{n}=2)$, leading to RE of $0.72 / 0.049=15$. Again, $k_{\text {uncat }}$ was the same $\left( \pm 0.002 \mathrm{M}^{-1} \mathrm{~s}^{-1}\right)$ either in the absence of RNA and presence of $\mathrm{Mg}^{2+}$ or in the presence of RNA and absence of $\mathrm{Mg}^{2+}$.

For anthracene in cis and DAB22, the anthracene was attached (as Anthr-HEG) to a 12-mer oligonucleotide representing the 5'-portion of the deoxyribozyme, and the remainder of the enzyme was provided as a separate 54-mer oligonucleotide. The length of stem I was $11 \mathrm{bp}$, which led to optimal rate constant values (see section above on "Testing secondary structure"). For DAB22 and DTME, we found observed first-order rate constant of $k_{\mathrm{obs}} \approx 3 \mathrm{~min}^{-1}$ under the standard deoxyribozyme conditions as used above (Figure S8A; at $50 \mu \mathrm{M}$ DTME this is equivalent to observed second-order rate constant of $1000 \mathrm{M}^{-1}$ $\mathrm{s}^{-1}$ ). For $k_{\mathrm{bkgd}}$, we found a similar $k_{\mathrm{bkgd}}$ value whether the DNA or $\mathrm{Ca}^{2+}$ was omitted. In both cases, $<4 \%$ of the product was formed at the highest timepoint of $100 \mathrm{~h}$, which means that $k_{\mathrm{bkgd}}$ is $<4 \% / 100 \mathrm{~h}=7 \times 10^{-6}$ $\min ^{-1}$ (at $50 \mu \mathrm{M}$ DTME this is equivalent to $k_{\mathrm{bkgd}}$ of $<0.0023 \mathrm{M}^{-1} \mathrm{~s}^{-1}$ ). Therefore, the RE is at least $\left(3 /\left[7 \times 10^{-6}\right]\right)=4 \times 10^{5}$.

For anthracene in cis and 39M49, the anthracene was attached (as Anthr-HEG) to a 15-mer oligonucleotide representing the 5'-portion of the ribozyme, and the remainder of the enzyme was provided as a separate 51-mer oligonucleotide. This corresponds to Jäschke's procedure ${ }^{3}$ and allows facile determination of rate constants by PAGE; Jäschke reported finding the same rate constant whether or not the 15-mer oligonucleotide was covalently attached to the remainder of the ribozyme. ${ }^{3}$ Jäschke reported $\mathrm{RE}$ of $2 \times 10^{4}$ using biotin-tethered maleimide as dienophile; this was the dienophile used during his 
original ribozyme selection effort. ${ }^{3}$ Jäschke later showed that NPM is a better dienophile than the biotinmaleimide, although the RE with NPM was not explicitly reported. ${ }^{10}$ We therefore determined RE for 39M49 using the optimal NPM as dienophile, which permits a fair comparison of RE values versus the DAB22 deoxyribozyme assayed with DTME as dienophile (see below). For 39M49 and NPM, we found observed first-order rate constant of $k_{\mathrm{obs}} \approx 5 \mathrm{~min}^{-1}$ (Figure S8B) under our standard ribozyme conditions as used above (at $50 \mu \mathrm{M}$ NPM this is equivalent to observed second-order rate constant of $1670 \mathrm{M}^{-1} \mathrm{~s}^{-1}$ ). For $k_{\text {bkgd }}$, we found the same value whether the RNA or $\mathrm{Mg}^{2+}$ was omitted. In both cases, $<20 \%$ of the product was formed at the highest timepoint of $100 \mathrm{~h}$, which means that $k_{\mathrm{bkgd}}$ is $<20 \% / 100 \mathrm{~h}=3.3 \times 10^{-5} \mathrm{~min}^{-1}$ (at $50 \mu \mathrm{M}$ NPM this is equivalent to $k_{\mathrm{bkgd}}$ of $\left.<0.011 \mathrm{M}^{-1} \mathrm{~s}^{-1}\right)$. Therefore, the RE is at least $\left(5 /\left[3.3 \times 10^{-5}\right]\right)=$ $1.5 \times 10^{5}$.

A DAB22 Diels-Alder deoxyribozyme

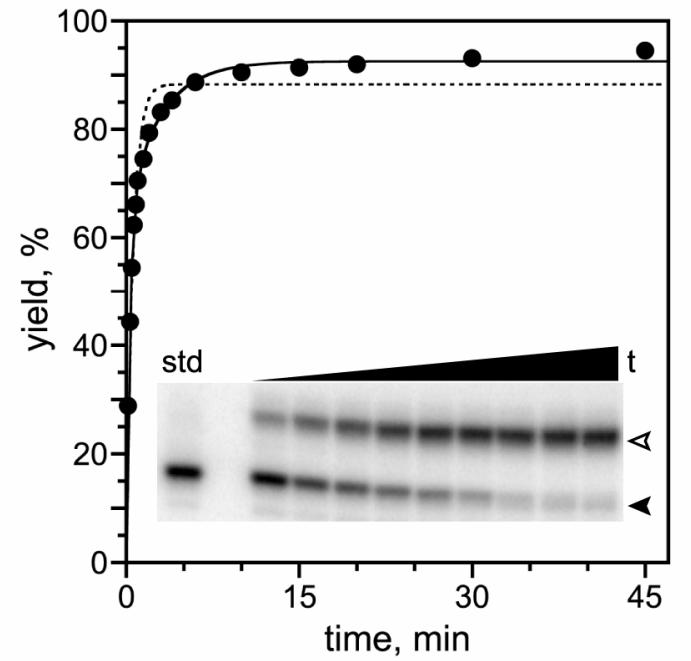

B 39M49 Diels-Alder ribozyme

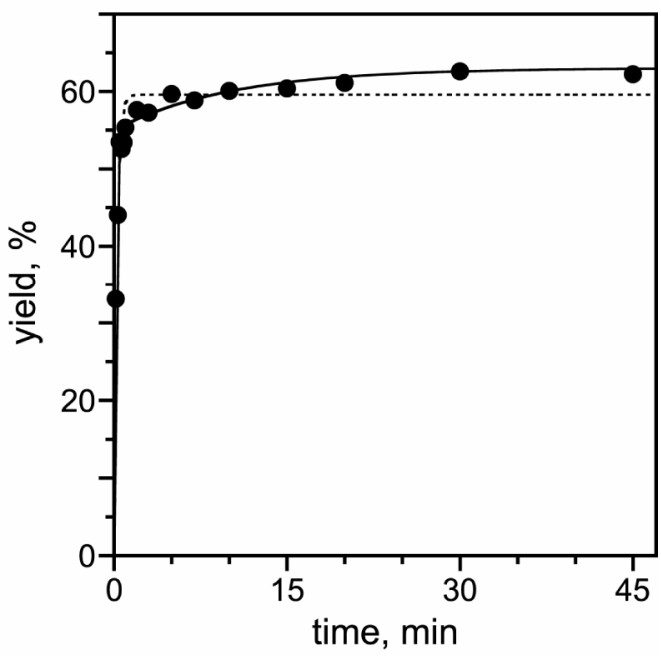

Figure S8. Determination of $k_{\mathrm{obs}}$ values for the DAB22 deoxyribozyme and 39M49 ribozyme with anthracene in cis. Assays were performed under the standard deoxyribozyme or ribozyme conditions as appropriate. (A) DAB22 with DTME as dienophile. (B) 39M49 with NPM as dienophile. The anthracene was attached to a 12-mer (DAB22) or 15mer (39M49) oligonucleotide, and the remainder of the ribozyme or deoxyribozyme was provided as a separate 54mer (DAB22) or 51-mer (39M49) oligonucleotide. Each data set was fit to a single exponential (dotted line) or a double exponential (solid line); the double exponentials clearly fit better. Curve fit parameters: DAB22 single exponential $1.8 \mathrm{~min}^{-1}$ (88\% yield); double exponential $3.1 \mathrm{~min}^{-1}(65 \%)$ and $0.34 \mathrm{~min}^{-1}(28 \%)$. 39M49 single exponential $4.2 \mathrm{~min}^{-1}\left(60 \%\right.$ yield); double exponential $5.3 \mathrm{~min}^{-1}(55 \%)$ and $0.10 \mathrm{~min}^{-1}(8 \%)$. In the gel image for the DAB22 assay, the filled arrowhead marks the position of the starting material, and the open arrowhead marks the position of the Diels-Alder product. Timepoints are shown at $\mathrm{t}=10,20,30,50$, and $90 \mathrm{~s} ; 3,8,15$, and $30 \mathrm{~min}$.

Michaelis-Menten $K_{\mathrm{m}}$ values for the DAB22 deoxyribozyme and 39M49 ribozyme

To provide information on the Michaelis-Menten parameters $K_{\mathrm{m}}$ and $V_{\max }$ for both DAB22 and 39M49, comprehensive kinetic data were collected in trans by the procedure described above (see representative data in Figure $\mathrm{S} 3$ ). For DAB22, the $V_{\text {init }}$ values were determined systematically at [Anthr-HEG] $=50$ to $500 \mu \mathrm{M}$ and $[\mathrm{DTME}]=50$ to $500 \mu \mathrm{M}$. For $39 \mathrm{M} 49$, the $V_{\text {init }}$ values were determined systematically at [Anthr-HEG] $=50$ to $400 \mu \mathrm{M}$ and [MCA] $=0.5$ to $4 \mathrm{mM}$, where MCA (maleimidocaproic acid) is a more water-soluble analog of NPM ( $N$-pentylmaleimide) as used by Jäschke. ${ }^{9}$ In all cases, the highest accessible concentration of each reagent was limited by solubility.

From sets of plots such as those in Figure S3, plots of $V_{\text {init }}$ versus [Anthr-HEG] and $V_{\text {init }}$ versus [maleimide] were constructed. These plots for DAB22 and various [Anthr-HEG] each at fixed [DTME] are shown in Figure S9; the other plots were of comparable quality. From each of these plots, the $V_{\max }$ 
value at the indicated [DTME] was determined from the curve fit to the standard saturation equation $V_{\text {init }}=V_{\max } \cdot[$ Anthr-HEG $] /(K+[$ Anthr-HEG] $)$, where the fit $K$ value was not considered further. Then, the $V_{\max }$ values were plotted as a function of [DTME] to obtain the best estimate of $K_{\mathrm{m}, \mathrm{DTME}}$ and the "true $V_{\max }$ " (by extrapolation of $V_{\max }$ to saturating DTME). This final plot for DAB22 and [DTME] is shown in Figure S10, with the analogous final plot for DAB22 and [Anthr-HEG] (which provides $K_{\mathrm{m}, \mathrm{Anthr}-\mathrm{HEG}}$ ) shown as well. Similarly, the final plots for 39M49 and [MCA] or [Anthr-HEG] are shown in Figure S11.

In all cases, the data are insufficient to derive $K_{\mathrm{m}}$ values any more precisely than as lower limits. For DAB22, from Figure S10 we conclude that $K_{\mathrm{m}, \mathrm{DTME}}$ is $>300 \mu \mathrm{M}$ and $K_{\mathrm{m} \text {,Anthr-HEG }}$ is $>200 \mu \mathrm{M}$. Similarly, for $39 \mathrm{M} 49$, from Figure $\mathrm{S} 11$ we conclude that $K_{\mathrm{m}, \mathrm{MCA}}$ is $>4 \mathrm{mM}$ and $K_{\mathrm{m}, \mathrm{Anthr}-\mathrm{HEG}}$ is $>200 \mu \mathrm{M}$. The greater magnitude of the lower limit for $K_{\mathrm{m}, \mathrm{MCA}}$ is a direct consequence of obtaining rate data at relatively high [MCA] due to the greater solubility of this compound (up to $4 \mathrm{mM}$ ). Our $K_{\mathrm{m}}$ values for $39 \mathrm{M} 49$ are consistent with those reported by Jäschke for this ribozyme. However, we feel that these type of data inherently do not permit the rather precise quantitative $K_{\mathrm{m}}$ values that were concluded in Jäschke's report (foonote $25 ; K_{\mathrm{m}, \mathrm{MCA}}$ of $5.2 \pm 1.3 \mathrm{mM}$ and $K_{\mathrm{m}, \mathrm{Anthr}-\mathrm{HEG}}$ of $200 \pm 35 \mu \mathrm{M}$ ). ${ }^{9}$
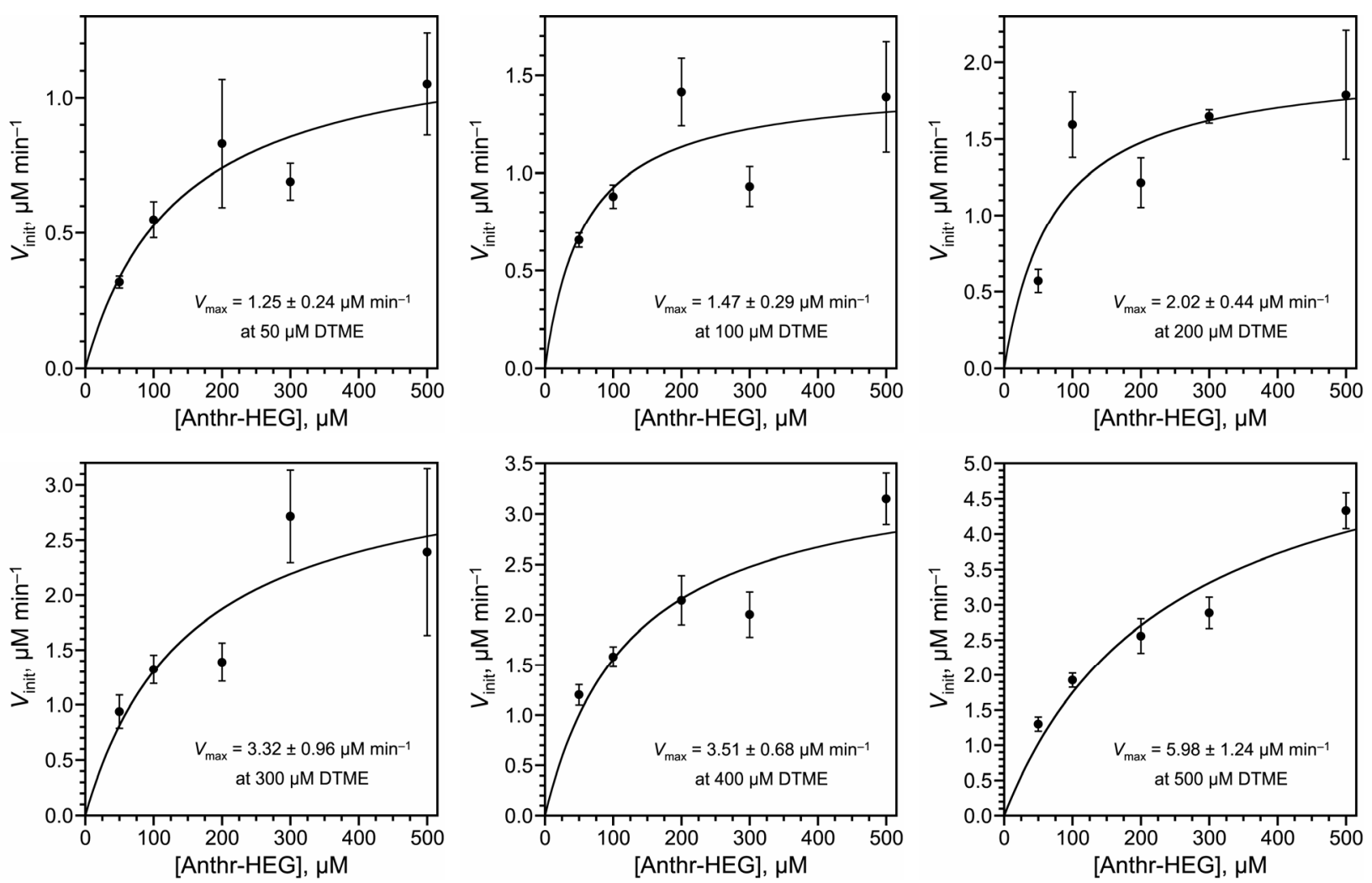

Figure S9. Plots of $V_{\text {init }}$ versus [Anthr-HEG] for the DAB22 deoxyribozyme in trans, derived from data similar to those of Figure S3. 

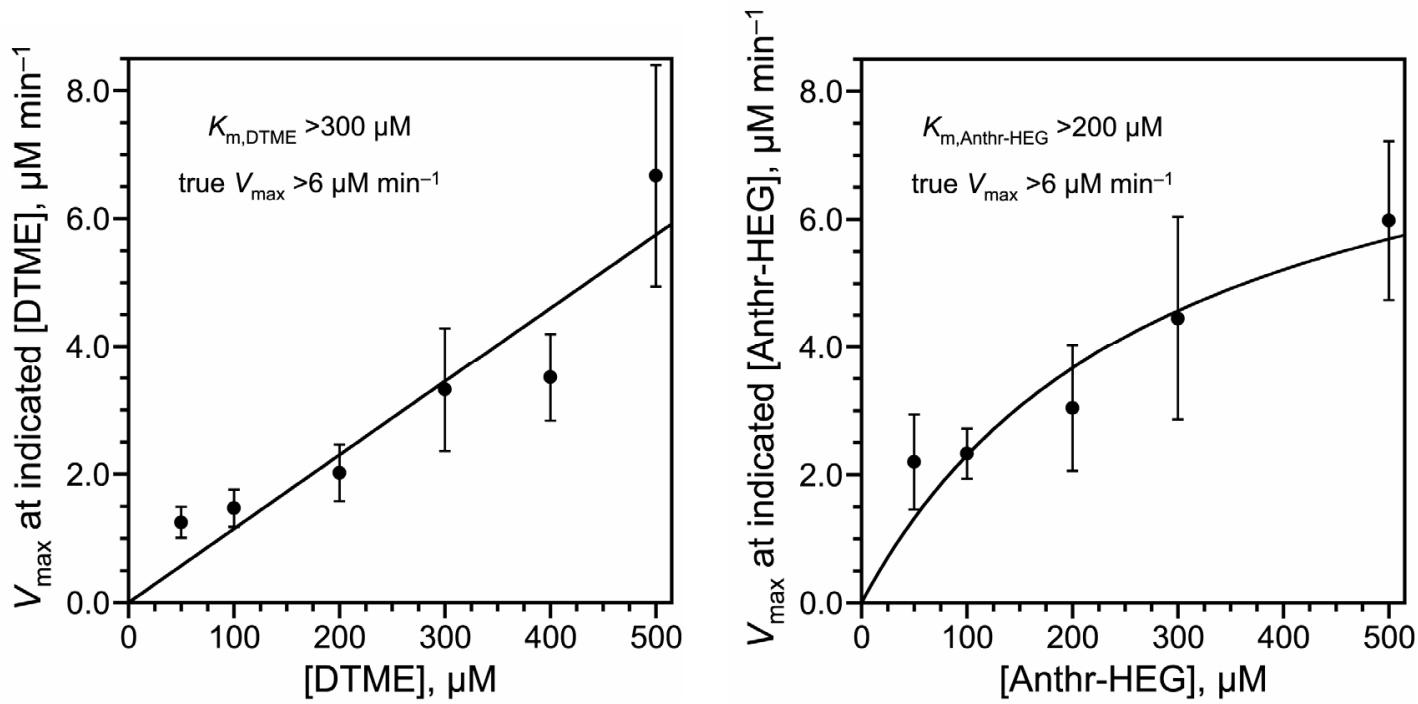

Figure S10. Plots of $V_{\max }$ versus [DTME] or [Anthr-HEG] for the DAB22 deoxyribozyme in trans, to provide estimates of $K_{\mathrm{m}, \mathrm{DTME}}$ and $K_{\mathrm{m}, \mathrm{Anthr}-\mathrm{HEG}}$ as lower limits.
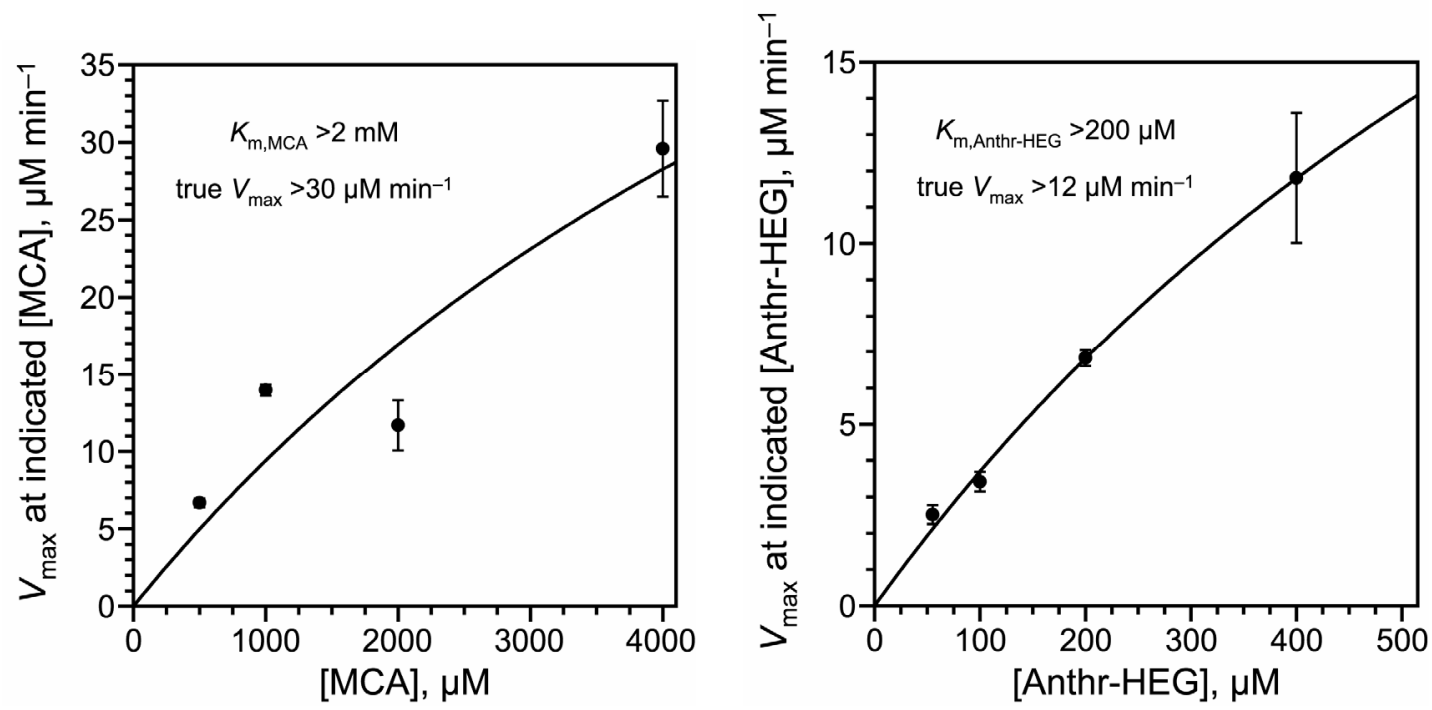

Figure S11. Plots of $V_{\max }$ versus [MCA] or [Anthr-HEG] for the 39M49 ribozyme in trans, to provide estimates of $K_{\mathrm{m}, \mathrm{MCA}}$ and $K_{\mathrm{m}, \mathrm{Anth}-\mathrm{HEG}}$ as lower limits. MCA $=$ maleimidocaproic acid, a more water-soluble analogue of NPM $=N$ pentylmaleimide. 
References for Supporting Information

(1) Seelig, B.; Jäschke, A. Site-Specific Modification of Enzymatically Synthesized RNA: Transcription Initiation and Diels-Alder Reaction. Tetrahedron Lett. 1997, 38, 7729-7732.

(2) Seelig, B.; Jäschke, A. Ternary conjugates of guanosine monophosphate as initiator nucleotides for the enzymatic synthesis of 5'-modified RNAs. Bioconjug. Chem. 1999, 10, 371-378.

(3) Seelig, B.; Jäschke, A. A small catalytic RNA motif with Diels-Alderase activity. Chem. Biol. 1999, 6, 167-176.

(4) Flynn-Charlebois, A.; Prior, T. K.; Hoadley, K. A.; Silverman, S. K. In Vitro Evolution of an RNACleaving DNA Enzyme into an RNA Ligase Switches the Selectivity from 3'-5' to 2'-5'. J. Am.

Chem. Soc. 2003, 125, 5346-5350.

(5) Flynn-Charlebois, A.; Wang, Y.; Prior, T. K.; Rashid, I.; Hoadley, K. A.; Coppins, R. L.; Wolf, A. C.; Silverman, S. K. Deoxyribozymes with 2'-5' RNA Ligase Activity. J. Am. Chem. Soc. 2003, 125 , 2444-2454.

(6) Wang, Y.; Silverman, S. K. Characterization of Deoxyribozymes That Synthesize Branched RNA. Biochemistry 2003, 42, 15252-15263.

(7) Langner, J.; Klussmann, S. PCR primers containing stop codons reduce the number of false-negatives during blue-white screening. BioTechniques 2003, 34, 950-954.

(8) Zuker, M. Mfold web server for nucleic acid folding and hybridization prediction. Nucleic Acids Res. 2003, 31, 3406-3415.

(9) Seelig, B.; Keiper, S.; Stuhlmann, F.; Jäschke, A. Enantioselective Ribozyme Catalysis of a Bimolecular Cycloaddition Reaction. Angew. Chem. Int. Ed. 2000, 39, 4576-4579.

(10) Stuhlmann, F.; Jäschke, A. Characterization of an RNA active site: interactions between a DielsAlderase ribozyme and its substrates and products. J. Am. Chem. Soc. 2002, 124, 3238-3244. 